\title{
PERAN MELANOKORTIN PADA MELANOSIT
}

\author{
Natalia F. E. Mamoto \\ Sonny J. R. Kalangi \\ Ronny Karundeng
}

\begin{abstract}
Bagian Anatomi-Histologi Fakultas Kedokteran Universitas Sam Ratulangi Manado. e-mail:sonnykalangi@yahoo.com
\end{abstract}

\begin{abstract}
Melanocyte, an important component of the skin pigmentation system, has the ability to produce and distribute melanin. This skin pigmentation system consists of melanocytes, melanosomes, tyrosinase enzymes, and the melanogenesis process. The biochemical process of the skin pigmentation (melanogenesis) is very complex, and produces eumelanin and pheomelanin pigments, both are tyrosine derivates. Melanocortins are found in the forms of $\alpha-\mathrm{MSH}, \beta-\mathrm{MSH}, \gamma-\mathrm{MSH}$, and ACTH. Melanocortins play some important roles in certain physiologic responses of human beings, such as: the skin pigmentation, adrenal function, sexual function, analgesia, temperature controle, cardiovascular controle, inflammatory process, energy homeostasis, endocrine secretion, diet-intake controle, and autonomic function. In general, the responses are proceeded by binding of melanocortins to their receptors.
\end{abstract}

Keyords: melanocyte, melanin, melanocortin, melanogenesis

\begin{abstract}
Abstrak: Melanosit merupakan komponen penting dalam sistem pigmentasi kulit melalui kemampuannya dalam menghasilkan dan mendistribusikan melanin. Sistem pigmentasi kulit melibatkan melanosit, melanosom, melanin, enzim tirosinase dan proses melanogenesis. Proses biokimia pigmentasi kulit (melanogenesis) bersifat sangat kompleks. Proses melanogenesis ini menghasilkan pigmen eumelanin dan feomelanin. Baik eumelanin maupun feomelanin keduanya adalah derivat tirosin melalui beberapa tahapan. Melanokortin terdiri atas $\alpha$-MSH, $\beta$-MSH, $\gamma$-MSH dan ACTH. Melanokortin terlibat dalam pengaturan respon fisiologi manusia, yaitu pigmentasi kulit, fungsi adrenal, fungsi seksual, analgesia, kontrol temperatur, kontrol kardiovaskuler, inflamasi, homeostasis energi, sekresi endokrin, mengontrol asupan makanan, dan fungsi otonom. Secara umum respon ini diawali dengan pengikatan melanokortin dengan reseptornya.
\end{abstract}

Kata kunci: melanosit, melanin, melanokortin, melanogenesis

Kulit merupakan barier utama terhadap sinar matahari serta merupakan target utama dari radiasi sinar ultraviolet. ${ }^{1}$ Paparan terhadap sinar matahari memiliki efek yang menguntungkan maupun merugikan terhadap tubuh manusia, tergantung pada lama dan frekuensi paparan, intensitas sinar matahari dan menyangkut sensitivitas masing-masing individu. Pada populasi yang banyak menghabiskan waktu di bawah sinar matahari, didapatkan meningkatnya kepedulian terhadap efek paparan sinar matahari yang merugikan dalam meningkatkan insidensi keganasan kulit, mempercepat penuaan dini dan perubahan kulit lainnya termasuk kelainan pigmentasi. $^{2}$

Melanosit adalah komponen penting dalam sistem pigmentasi kulit lewat kemampuannya dalam menghasilkan dan mendistribusikan melanin. Umumnya melanosit ditemukan di kulit tetapi juga ditemukan pada beberapa tempat yang lain misalnya pada lepto-meningens di 
otak dan mata. ${ }^{4}$ Pada kulit, melanosit terdapat pada lapisan basal epidermis atau dalam dermis di bawahnya dan menjulurkan banyak cabang sel di antara keratinosit sekitarnya. ${ }^{5}$

Sistem pigmentasi kulit melibatkan melanosit, melanosom, melanin, enzim tirosinase dan proses melanogenesis. ${ }^{6}$ Melanosom merupakan organel spesifik yang dibentuk oleh melanosit yang merupakan tempat pembentukan melanin sekaligus sebagai alat transport melanin dari melanosit menuju keratinosit. ${ }^{4,6} \mathrm{Me}-$ lanin merupakan pigmen yang dihasilkan oleh melanosit dari polimerisasi dan oksidasi pada proses melanogenesis dan pembentukannya memerlukan adanya enzim tirosinase. ${ }^{4,6}$ Enzim tirosinase berfungsi dalam oksidasi pada proses melanogenesis, secara genetik enzim tirosinase berlokasi di dalam kromosom nomor $11 .^{6}$

Pigmentasi kulit mungkin tergantung pada beberapa pengaruh termasuk faktor keturunan/genetik (warna kulit konstitutif), hormon dan lingkungan (warna kulit fakultatif). ${ }^{6-8}$ Faktor genetik mempengaruhi ukuran satuan melanin epidermis dan melanosom serta produksi melanin. Faktor lingkungan seperti pajanan sinar matahari meningkatkan kegiatan enzim tirosinase sehingga meningkatkan produksi melanin dan penimbunannya di dalam keratinosit sehingga mencoklat (tanning).,

Pada penelitian yang dilakukan pada tahun 1961 oleh Lerner dan McGuire melaporkan bahwa penyuntikan dengan konsentrasi tinggi dari alpha-Melanocyte Stimulating Hormone ( $\alpha$-MSH) dan bethaMelanocyte Stimulating Hormone ( $\beta$ MSH) pada manusia menyebabkan penggelapan kulit. Akan tetapi penelitian ini tidak membuktikan peran dari melanokortin secara spesifik terhadap melanosit, atau keberadaan Melanocortin-1 Receptor (MC1R) yang spesifik pada sel-sel ini. Nanti pada tahun 1992 oleh Mountjoy dkk ditemukan adanya ekspresi MC1R pada melanosit epidermal manusia. Melanosit yang dikultur tersebut menunjukkan respon terhadap $\alpha$-MSH dengan meningkatkan proliferasi melanosit dan melano- genesis. $^{3,9}$

Melanokortin terdiri atas $\alpha-\mathrm{MSH}$, $\beta$-MSH, $\gamma$-MSH (gamma- Melanocyte Stimulating Hormone) dan Adrenokortikotropin (ACTH) yang berasal dari proopiomelanocortin (POMC). ${ }^{10}$ Dalam mengatur pigmentasi kulit, melanokortin berikatan dengan reseptornya yaitu MC1R yang terletak pada permukaan melanosit. ${ }^{3}$ Aktivitas MC1R diatur oleh faktor instrinsik dan ekstrinsik dan yang paling penting adalah radiasi ultraviolet matahari. ${ }^{11}$ Keratinosit dan melanosit menyekresikan melanokortin khususnya $\alpha-\mathrm{MSH}$ dan ACTH sebagai respon terhadap radiasi ultraviolet matahari. Hormon-hormon tersebut berperan sebagai faktor parakrin dan autokrin terhadap melanosit dalam pengaturan pigmentasi kulit yang diinduksi oleh radiasi ultraviolet matahari. ${ }^{3,9,11}$

\section{MELANOSIT}

Melanosit adalah sel khusus yang terdapat dalam stratum basal epidermis atau dalam dermis di bawahnya dan menjulurkan banyak cabang sel yang disebut dendrit di antara keratinosit sekitarnya. ${ }^{5}$ Melanosit merupakan sel yang dapat menyintesis enzim tirosinase, enzim tersebut jika bergabung dalam melanosom, dapat memulai sintesis dan deposit dari melanin. ${ }^{14}$ Oleh sebab itu melanosit adalah komponen penting dalam sistem pigmentasi kulit. ${ }^{3}$

\section{Embriogenesis melanosit}

Melanosit epidermal berkembang dari krista neuralis dan bermigrasi ke berbagai tempat dalam bentuk melanoblast. Melanoblast kulit hanya terdapat di dermis yang mengalami deferensiasi menjadi melanosit dan tampak dalam epidermis pada kehidupan janin minggu kesebelas. ${ }^{4}, 15$

Pada minggu kedua sesudah pembuahan bagian dorsal embrio menebal membentuk neural plate, kemudian neural plate membangun sebuah alur yang akan menjadi neural tube dan 
kemudian membentuk spinal cord. Pada minggu ketiga sampai keempat sesudah pembuahan neural tube menutup. Sel-sel krista neuralis berlokasi antara neural tube dan lapisan epidermis. Pada minggu kelima sesudah pembuahan sel-sel krista neuralis bermigrasi melalui mesoderm ke jaringan-jaringan lain. Migrasi tidak mencapai semua tempat di tubuh secara bersamaan. Beberapa di antaranya menjadi melanoblast yang merupakan prekursor melanosit. ${ }^{16}$ Pada minggu keenam sesudah pembuahan pembentukan krista neuralis menjadi lengkap. ${ }^{17}$ Pada minggu ketujuh sesudah pem-buahan melanosit di dermis mempunyai premelanosom pada sitoplasmanya. Sesudah minggu ketujuh kepadatan populasi melanosit epidermis meningkat dan memuncak sekitar $2300 \mathrm{sel} / \mathrm{mm}^{2}$ pada trimester kedua. Kemudian mengalami penurunan sampai sesudah lahir dengan kepadatan populasi melanosit sekitar $800 \mathrm{sel} / \mathrm{mm}^{2}$. Pada minggu kesepuluh sesudah pembuahan melanosit sudah mengandung melanosom dan menunjukkan proses awal melanisasi. ${ }^{6}$

\section{Histologi melanosit}

Pada sajian kulit berpigmentasi normal yang diwarnai dengan hematoksilin eosin (HE), melanosit tidak tampak sebagai sel berpigmen, karena cabangcabang sitoplasmanya sukar diamati. Sebaliknya melanosit secara insidental tampak sebagai sel jernih yang terdapat di stratum basal, oleh sebab itu melanosit disebut sel jernih (clear cell) bersama dengan sel-sel yang lain yang juga nampak sebagai sel jernih. Oleh sebab itu sulit untuk membedakan melanosit terhadap sel jernih lain-nya dengan pewarnaan $\mathrm{HE}$. Daerah jernih di sekeliling inti sebagian karena sitoplasma kurang basofil daripada keratinosit sekelilingnya dalam stratum basal, sebagian karena cenderung untuk mengerut. ${ }^{4}$ Bentuk selnya sukar ditetapkan. 5

Cara terbaik untuk mengidentifikasi melanosit adalah menggunakan reaksi DOPA (dihydroksyphenylalanine) yaitu epidermis yang telah dikupas dari dermis kemudian diinkubasi dalam suatu bakal untuk melanin yaitu DOPA. DOPA dioksidasi oleh enzim tirosinase di dalam melanosit untuk menghasilkan melanin coklat tua, sedangkan sitoplasma melanosit terpulas agak kelabu. ${ }^{4,7,15}$

Pada sajian tampak badan sel berbentuk bulat sampai lonjong atau sedikit bersudut tampak di bagian basal epidermis, tetapi selalu pada sisi epi-dermal dari membrana basalis, yang dapat menonjol ke dermis di bawahnya., ${ }^{45}$ Dari sudut badan sel, biasanya tampak empat atau lima cabang dendrit, yang percabangannya ke arah horizontal dan ke atas dalam ruang-ruang di antara keratinosit. ${ }^{4}$ Cabang-cabang ini menjadi semakin tipis dan akhirnya berakhir membentuk pentul kecil di permukaan keratinosit, kadang cabang-cabang dendrit melanosit berjarak $100 \mu \mathrm{m}$ dari badan selnya. Percabangan ini tampak membentuk jala-jala yang hampir kontinyu di bagian basal epidermis. ${ }^{4}$ Tampak pula membran sitoplasma yang halus. ${ }^{17}$

Dendrit melanosit memanjang di antara keratinosit-keratinosit sekitarnya dan dapat bergerak. Mereka dapat memanjang atau memendek sesuai kebutuhan pada area-area berbeda di sekitar melanosit. ${ }^{16}$ Pada daerah dengan kepadatan melanosit yang kurang, dendrit melanosit lebih panjang dibandingkan dengan daerah yang lebih padat. Sedangkan pada jaringan lain seperti uvea dan retina tidak terdapat dendrit. ${ }^{6}$

Dengan mikroskop elektron terlihat melanosit berwarna pucat. ${ }^{15}$ Melanosit merupakan sel kelenjar yang khas. ${ }^{4}$ Sitoplasmanya dipenuhi dengan organelorganel dan granula karakteristik yang disebut melanosom pada berbagai tingkat kematangan. ${ }^{6,17}$ Melanosit mempunyai inti bulat sampai lonjong yang dikelilingi sejumlah mitokondria dan vesikel. Melanosit juga mempunyai organelorganel yang lain yaitu mikro-filamen (5$7 \mathrm{~nm})$, filamen inter-media $(10 \mathrm{~nm})$, mikrotubulus $(\mathrm{D}=25-27 \mathrm{~nm})$, retikulum endoplasma halus, retikulum endoplasma kasar dengan sisterna pendek, dan 
aparatus golgi yang menonjol. Filamen intermedia dan mikro-tubulus terlibat dalam pemindahan melanosom dari melanosit ke dalam keratinosit yang berbatasan dengannya. ${ }^{6,15-17}$

Melanosit mudah dikenal karena tidak mempunyai tonofibril dan desmosom namun mempunyai dendrit. ${ }^{6}$ Melanosit tidak melekat dengan sel-sel lain atau dengan lamina basalis dengan menggunakan hemidesmosom, desmosom atau anchouring fibril. ${ }^{4,16}$ Tetapi melanosit memiliki struktur yang mirip dengan desmosom yang disebut melanocyte dense plate. $^{17}$ Melanosit cenderung mengerut karena tidak memiliki desmosom. ${ }^{4}$

Setiap melanosit berhubungan dengan 30-40 keratinosit dan beberapa sel Langerhans membentuk unit melanin epidermis. ${ }^{3,16,17}$ Tidak semua daerah pada tubuh memiliki jumlah melanosit yang sama, rasio melanosit terhadap sel-sel basal epidermis berkisar antara 1:4 sampai 1:10.,

Jumlah melanosit tiap milimeter persegi lapisan kulit berbeda-beda, rata-rata sekitar $1500 \mathrm{sel} / \mathrm{mm}^{2}$ dengan berat lebih kurang satu gram. ${ }^{6}$ jumlahnya sekitar 2000 $\mathrm{sel} / \mathrm{mm}^{2}$ di bagian-bagian permukaan tubuh yang pigmennya banyak, misalnya di wajah dan organ genital, sedangkan yang di bagian tubuh lainnya jumlahnya 1000 $\mathrm{sel} / \mathrm{mm}^{2}{ }^{4,5,15,21}$ Tidak terdapat perbedaan bermakna antara jumlah melanosit pada laki-laki dan wanita demikian pula pada perbedaan ras maupun keturunan. ${ }^{5-7,15,17,21}$ Perbedaan warna kulit disebabkan oleh: jumlah melanin yang dihasilkan dan dipindahkan, ${ }^{5,17}$ aktivitas melanosit, ${ }^{17,21}$ jumlah, ukuran dan degradasi melanosom dalam keratinosit, ${ }^{6,7,21}$ stadium pembentukan melanin dari melanosom, ${ }^{22}$ dan agregasi melanin dalam keratinosit. ${ }^{22}$

Melanosit akan bertambah jumlah dan aktivitasnya karena paparan sinar ultraviolet. ${ }^{21}$ Dengan bertambahnya usia, jumlah melanosit yang aktif mengalami penurunan. Sejumlah melanosit epidermal mulai berkurang pada umur 40 tahun, dan melanosit menjadi lebih besar dan lebih dendritik. $6,16,17$

\section{Peran melanosit}

Melanosit dapat memproduksi dan mendistribusikan melanin, karenanya berfungsi sebagai komponen penting terhadap sistem pigmentasi kulit. ${ }^{3}$

Sebagai komponen suatu sistem jaringan pengatur, melanosit menghasilkan beberapa sitokin antara lain IL-1 (Interleukin-1), IL-6 (Interleukin-6) dan TNF- $\alpha$ (Tumor Necrotic Factor- alpha) yang bekerja menghambat proses melanogenesis melalui penurunan aktivitas enzim tirosinase dan proliferasi melanosit. $^{6}$

Melanosit dapat menghasilkan neuropeptida dan neuro-transmiter yang merupakan komponen penting terhadap jalur komunikasi antara kulit dan sistem saraf pusat. $^{3}$

Sebagai komponen sistem imun kulit, melanosit mampu mengekspresikan molekul major histocompatibility complex (MHC) kelas II, intercellular adhesion molecule-1 (ICAM-I) dan menghasilkan beberapa sitokin. Melanosit mampu berfungsi sebagai fagositosis dan mempunyai melanosom yang seolaholah bertindak sebagai lisosom (lysosome like function). ${ }^{6}$

\section{MELANOSOM}

Melanosom adalah organel spesifik yang dibentuk oleh melanosit yang merupakan tempat pembentukan melanin sekaligus sebagai alat transport melanin dari melanosit menuju keratinosit., Istilah melanosom digunakan untuk tahap akhir yang memberi DOPA positif. ${ }^{4}$

\section{Proses melanisasi dalam melanosom}

Tingkat I merupakan pembentukan melanosom dari matriks protein. Pada tingkat ini melanosom berbentuk sferis atau lonjong. Berisi enzim tirosinase dan sedikit filamen, namun belum ada melanin. Tingkat II, eumelanosom berbentuk lonjong dengan sub-struktur yang lamelar, feo-melanosom berbentuk bulat dengan substruktur yang tidak teratur. Melanosom berisi banyak filamen namun 
masih belum didapatkan melanin. Tingkat III, aktivitas enzim tirosinase meningkat, melanin telah terbentuk, dimana sebagian menutupi filamen sehingga gambarannya kabur. Tingkat IV melanosom berisi banyak melanin. ${ }^{11,16,17,21}$

\section{Histologi melanosom}

Melanosom berukuran sekitar 0,6$1,3 \mu \mathrm{m} \quad \mathrm{X} \quad 0,4 \mu \mathrm{m}$ ukuran tersebut dipengaruhi oleh faktor genetik. Melanosom pada kulit hitam (Negroid) berukuran sekitar 1-1,3 $\mu \mathrm{m}$ dengan kandungan melanin lebih banyak serta proses degradasi lebih lambat dibandingkan dengan kulit putih (Kaukasoid atau Mongoloid) yang memiliki ukuran melanosom sekitar 0,6$0,7 \mu \mathrm{m} .{ }^{4,6}$ Pada permukaan dalam melanosom terdapat lamel-lamel yang tersusun konsentris ke arah sumbu panjang organel. $^{4}$

Terdapat dua jenis melanosom yang berhubungan dengan tipe melanin yang dihasilkan yaitu eumelanosom yang berbentuk elips dan berisi matriks fibriler dan feomelanosom yang bentuknya bermacammacam, kebanyakan bulat dan berisi matriks vesikuloglobular. ${ }^{11}$

\section{Transfer melanosom ke keratinosit}

Setelah melanosom mengalami melanisasi (tingkat III dan IV) kemudian melanosom dipindahkan ke dalam keratinosit. ${ }^{6}$ Selanjutnya melanosom ditransfer oleh filamen intermedia menuju ke ujung dendrit melanosit. ${ }^{17}$ Mekanisme sebenarnya pemindahan ini, yaitu granula melanin yang utuh ditimbun dalam sitoplasma keratinosit, belum diketahui dengan pasti. ${ }^{4}$

Proses pemindahan ini diduga terjadi dalam beberapa hal, antara lain: ${ }^{4}$

1. Proses "penjepitan" ujung dendrit yang menuju keratinosit diikuti dengan proses "mencerna" dan memindahkan ke keratinosit.

2. Adanya "membran" antara melanosit dan keratinosit yang membentuk jalan bagi pelepasan melanosom.

3. Lepasnya melanosom dari melanosit menuju ruang interseluler diikuti proses endositosis oleh keratinosit.

4. Inokulasi secara langsung. Berkaitan dengan teori Masson dari suatu "inokulasi". Dengan mikroskop elektron menunjuk-kan bahwa segmen dendrit berisi melanosom menembus keratinosit dan akhirnya melanosom lepas dan hal ini diamati dengan mikro-sinematografi pada kultur sel.

\section{Degradasi melanosom}

Selama perpindahan sel-sel epidermis ke permukaan kulit, melanosom dikumpulkan dalam vesikel yang berbatas membran (pada ras kulit putih) disebut kompleks melanosom yang mempunyai ciri lisosom. Dalam vesikel-vesikel ini, granula melanin mengalami pemecahan secara bertahap oleh aktivitas enzim lisosom. Sebaliknya pada orang negro, melanosom tetap sebagai granula tunggal dalam sitoplasma keratinosit selama migrasi dan keratinisasi. ${ }^{4}$ Sub-struktur dari melanosom didegradasi secara enzimatik, tetapi polimer melanin yang disebut "melanin dust" bersifat sangat stabil. ${ }^{17}$ Tidak diketahui enzim apa yang mendegradasi polimer melanin. ${ }^{16} \mathrm{Me}-$ lanosom didegradasi di dalam keratinosit selama keratinosit naik menuju permukaan epidermis dan akhirnya "melanin dust" hilang bersama lepasnya stratum korneum. ${ }^{8,21}$

\section{MELANIN}

Melanin merupakan pigmen yang dihasilkan oleh melanosit dari polimerisasi dan oksidasi pada proses melanogenesis dan pembentukannya memerlukan adanya enzim tirosinase. ${ }^{4,6}$

Istilah granula melanin digunakan dalam mikroskop cahaya dan terdiri atas melanosom yang berisi melanin. ${ }^{4}$

\section{Jenis-jenis melanin}

Terdapat dua tipe pigmen melanin utama, antara lain :

1. Eumelanin

Pigmen ini memberikan warna 
coklat atau coklat gelap dan hitam. Tidak larut dalam semua macam larutan, mempunyai berat molekul tinggi, mengandung nitrogen dan terjadi oleh karena proses oksidasi dan polimerisasi bentuk 5,6 dihidroksiindol dan 5,6 dihidroksiindol 2 asam karboksil.

2. Feomelanin

Pigmen ini memberi warna cerah, yaitu kuning hingga coklat kemerahan. Larut terutama dalam alkali, mengandung nitrogen dan sulfur dan terjadi oleh karena proses polimerisasi sistenil dopa.

Selain itu juga dikenal tipe pigmen yang lain, yaitu oksimelanin, trichrome, melanin campuran (mixed type melanins) dan neuromelanin. ${ }^{6}$

\section{Fungsi melanin}

- Memberi warna pada kulit

- Sebagai substansi fotoproteksi (tabir surya alami)

- Sebagai komponen pengikat obat (drugs-binding agents)

- Sebagai "energy tranducer" melanin mampu mengubah beberapa bentuk energi menjadi panas dan kemudian dilepaskan. ${ }^{6}$

\section{Melanogenesis}

Proses biokimia pigmentasi kulit (melanogenesis) bersifat sangat kompleks. Proses melanogenesis ini menghasilkan pigmen eumelanin dan feomelanin. Baik eumelanin maupun feomelanin keduanya adalah derivat tirosin melalui beberapa tahapan.

Tirosin mengalami proses oksidasi menjadi 3,4-dihidroksi-fenilalanin (DOPA) oleh aktivitas enzim tirosinase dan kemudian dioksidasi lagi menjadi bentuk dopakuinon. Setelah tahap ini, jalur melanogenesis terbagi menjadi dua bagian, yaitu eumelanogenesis dan feomelanogenesis.

Pada jalur eumelanogenesis, senyawa dopakuinon mengalami oksidasi menjadi bentuk leuko-dopakrom (siklodopa) yang secara cepat pula berubah menjadi bentuk dopakrom. Selanjutnya dopakrom mengalami perubahan bentuk menjadi 5,6 dihidroksiindol dan 5,6 dihidroksiindol 2 asam karboksilik. Pada tahap akhir pembentukan pigmen eumelanin apakah lebih dipengaruhi oleh polimerisasi senyawa 5,6 dihidroksiindol atau 5,6 dihidroksiindol 2 asam karboksilik sampai saat ini masih kontroversial.

Pada jalur feomelanogenesis, penambahan kelompok sulfhidril (sistein ataupun glutation) pada senyawa dopakuinon, akan menyebabkan reaksi nonenzimatis secara cepat pada metabolisme melanosit sehingga terbentuk senyawa sisteinildopa. Kemudian senyawa ini mengalami oksidasi menjadi benzotizinilalanin sampai pada tahap terbentuknya pigmen feomelanin. ${ }^{6}$

\section{MELANOKORTIN}

Melanokortin terdiri atas $\alpha-\mathrm{MSH}$, $\beta$-MSH, $\gamma$-MSH dan ACTH. ${ }^{9,10,24}$ Rangkaian asam amino dari melanokortin dimurnikan dan dirangkaikan pada tahun 1950an menunjukkan $\alpha$ dan $\beta$-MSH dan $\mathrm{ACTH} .{ }^{24}$ Melanokortin berasal dari suatu prohormon yaitu POMC. ${ }^{10}$ POMC diekspresikan dan mengalami pemecahan secara proteolitik pada sejumlah tempat di tubuh misalnya kelenjar hipofisis dan kulit, dimana keratinosit kelihatannya merupakan sumber utama dari peptida ini. POMC juga dihasilkan dalam melanosit, sel Langerhans dan sistem imun. $^{3,16,25}$

Melanokortin terlibat dalam pengaturan yang luas dari respon fisiologi manusia yaitu pigmentasi kulit, fungsi adrenal, fungsi seksual, analgesia, kontrol temperatur, kontrol kardio-vaskuler, inflamasi, homeostasis energi, sekresi endokrin, mengontrol masukan makanan, dan fungsi otonom. ${ }^{22,24-26}$ Secara umum respon ini diawali dengan pengikatan melanokortin dengan reseptornya. ${ }^{5}$

\section{Biosintesis dan sekresi melanokortin}

ACTH dan $\beta$-lipotropin berasal dari molekul protein yang lebih besar yang dihasilkan oleh sel-sel kortikotrop pars 
distalis kelenjar hipofisis dan sel basofil pars intermedia kelenjar hipofisis yang diduga identik dengan kortikotrop. Bakal molekul ini diberi nama ACTH besar atau pro-opikortin atau POMC. Di sel-sel kortikotrop pars distalis POMC dibelah menjadi ACTH dan $\beta$-lipotropin oleh Prohormon Convertase-1 (PC-1), sedangkan di sel-sel basofil pars intermedia mengalami hidrolisis selanjutnya menjadi $\alpha$-MSH, $\quad \beta$-MSH, $\quad$ Corticotropin-like Intermediate Lobe Peptida (CLIP), $\beta$ endorfin, $\gamma$-endorfin dan metenkafalin oleh Prohormon Convertase -2 (PC-2), ${ }^{4,9,27}$

Pars intermedia pada manusia hanya merupakan 2\% dari kelenjar hipofisis, sedangkan sebagian besar sel-sel di primodium pars intermedia bermigrasi ke pars distalis dan disini menyusun ACTH dan $\beta$-lipotropin. ${ }^{4}$ Tempat utama yang menghasilkan MSH adalah pars intermedia dari kelenjar hipofisis. Karena pars intermedia pada manusia hanya sedikit maka hanya mensekresi dengan jumlah yang sedikit kecuali pada keadaan patologi. ${ }^{3}$

Selain di hipofisis, melanokortin dihasilkan juga di kulit. Keratinosit epidermal merupakan sumber utama dari peptida ini, selain itu melanokortin dihasilkan juga oleh melanosit dan sel langerhans., Keratinosit dan melanosit mensekresikan melanokortin khususnya $\alpha-\mathrm{MSH}$ dan ACTH sebagai respon terhadap radiasi ultraviolet dari sinar matahari. Oleh sebab itu melanokortin dapat berperan sebagai faktor parakrin dan autokrin dalam pengaturan melanosit dan pigmentasi kulit. ${ }^{3,11}$

\section{Struktur melanokortin}

Adrenokortikotropin adalah polipeptida sederhana terdiri atas 39 asam amino, dimana 23 dari rangkaian pertama mempunyai aktivitas hormon penuh dan sebagai inti yang aktif., ${ }^{4,27}$

MSH adalah suatu polipeptida yang terdapat dalam tiga bentuk yaitu $\alpha$ MSH, $\beta$-MSH dan $\gamma$-MSH. $\alpha$-MSH terdiri atas 13 asam amino, $\beta$-MSH terdiri atas 18 asam amino dan $\gamma$-MSH terdiri atas 12 asam amino., ${ }^{4,14}$

Beta lipotropin ( $\beta$-LPH) adalah suatu polipeptida linear dengan 91 asam amino, yang terdiri dari rangkaian asam amino $\beta$-endorfin (yang selanjutnya berisi rangkaian asam amino metenkephalin). $\beta$-lipotropin dan metenkephalin berikatan pada reseptor opiat. ${ }^{4}$

CLIP dan $\gamma$-endorfin tidak menunjukkan fungsi fisiologis. ${ }^{4}$

\section{RESEPTOR MELANOKORTIN}

Reseptor melanokortin merupakan bagian dari G-protein-coupled receptors (GPCRs) dengan tujuh helix transmembran, dan merupakan reseptor G-protein-coupled yang terkecil. ${ }^{24}$ GPCRs menyebabkan produksi zat siklik adenosin monofosfat (cAMP) sebagai respon dari rangsangan peptida. ${ }^{25}$ Terdapat lima reseptor melanokortin yang sudah berhasil diklon yaitu Reseptor melanokortin 1 (MC1R), Reseptor melanokortin-2 (MC2R), Reseptor melanokortin-3 (MC3R), Reseptor melanokortin-4 (MC4R) dan Reseptor melanokortin-5 (MC5R). ${ }^{24}$

\section{MC1R}

Reseptor melanokortin-1 (MC1R) disebut juga Melanocyte Stimulating Hormone Receptor (MSH-R) atau Melanotropin receptor. ${ }^{22} \mathrm{MC1R}$ terdiri atas 317 asam amino, merupakan reseptor untuk MSH dan ACTH. ${ }^{11,24,29,30}$ MC1R terletak pada kromosom 16q24.3. ,11,29 $^{2}$ Diekspresikan oleh melanosit dan lekosit $^{31}$ Pada setiap melanosit di epidermis kira-kira terdapat 1000 tempat pengikatan. ${ }^{9,25}$ MC1R berperan dalam pigmentasi dan infla-masi. ${ }^{31}$ Afinitasnya terhadap $\alpha$ $\mathrm{MSH} \geq \mathrm{ACTH}>\beta-\mathrm{MSH}>\gamma$-MSH. ${ }^{11,24}$ $\gamma$-MSH memiliki afinitas yang paling kecil terhadap MC1R, sehingga tidak mem-punyai peran yang berarti terhadap pig-mentasi kulit. ${ }^{9}$ Aktivitas dari MC1R diatur oleh faktor instrinsik dan ekstrinsik dimana dan paling penting adalah radiasi ultraviolet matahari. ${ }^{3}$ 


\section{MC2R}

Reseptor melanokortin-2 (MC2R) disebut juga Adrenocorticotrophic Hormone Receptor (ACTH-R). ${ }^{22,24} \mathrm{MC} 2 \mathrm{R}$ terdiri dari 297 asam amino dan diekspresikan di korteks adrenal. Diaktifkan secara selektif oleh ACTH. ${ }^{11,22,26,33}$ Berperan dalam sekresi steroid. ${ }^{26}$

\section{MC3R}

Reseptor melanokortin-3 (MC3R) terdiri dari 360 asam amino dan diekspresi di otak, plasenta dan gut. ${ }^{22,24,31,33}$ MC3R berperan dalam homeostasis energi tetapi tidak berperan dalam pigmentasi. ${ }^{11,24,26}$

\section{MC4R}

Pada tahun 1993 Gantz dkk melaporkan kloning, akspresi dan lokasi gen dari Reseptor melanokortin-4 (MC4R). MC4R terdiri dari 332 asam amino dan diekspresikan di otak. ${ }^{22,24,31,33}$ MC4R berlokasi pada kromosom 18q22 dan dikode oleh single exon. Meskipun MC4R ditemukan sepanjang sistem saraf pusat, tetapi ekspresi MC4R yang terbanyak terdapat pada hipotalamus, yang merupakan bagian otak pengatur masukan makanan dan kontrol berat badan. MC4R berperan dalam pengaturan berat badan, fungsi seksual, keadaan emosi, respons stress dan lain-lain, tetapi tidak berperan dalam pigmentasi. ${ }^{11,24,34}$ Peran MC4R dalam pengaturan berat badan dan masukan makanan dapat dimanfaatkan untuk pengobatan obesitas sebagai efek sekunder dari obat-obat agonis MC4R. ${ }^{34}$

\section{MC5R}

Reseptor melanokortin-5 (MC5R) terdiri dari 325 asam amino dan diekspresikan pada kelenjar eksokrin dan otak. ${ }^{31}$ MC5R terutama berperan dalam pengaturan fungsi kelenjar eksokrin khususnya sekresi kelenjar sebaseus dan respon imun tetapi tidak berperan dalam pigmentasi. Peran MC5R dalam pengaturan sekresi kelenjar sebaseus dapat dimanfaatkan sebagai pengobatan terhadap gangguan pada kulit misalnya jerawat dan dermatitis. ${ }^{11,24,31}$

\section{Mekanisme kerja melanokortin}

Dalam mengatur pigmen-tasi kulit melanokortin berikatan dengan reseptornya yaitu MC1R yang terletak pada permukaan melanosit. ${ }^{3}$ Sesudah berikatan dengan MC1R, bagian reseptor yang menonjol ke dalam membran sel diaktifkan menjadi enzim protein adenil siklase. Enzim ini selanjutnya menyebabkan konversi adenosin trifosfat (ATP) sitoplasmik menjadi cAMP intraseluler. Kemudian cAMP akan menyebabkan pengaktifan protein kinase A (PKA) yang selanjutnya akan mengaktifkan transkripsi gen tirosinase yang berlokasi di kromosom 11 dengan beberapa mekanisme. Gen ini kemudian ditranslasi ke dalam peptida pada retikulum endoplasma kasar. Vesikel dari retikulum endoplasma kasar mengantar enzim tirosinase ini ke badan golgi. Bentuk terglikosilasi dari tirosinase diangkut dari badan golgi pada vesikel clathrin-coated lewat sitoplasma ke melanosom dan bergabung dengan melanosom tersebut. Melanosom dibentuk dari retikulum endoplasma halus. Dengan bergabungnya vesikel ini dengan melanosom maka pembentukan melanin dimulai. ${ }^{16,35}$

Transduksi sinyal reseptor MSH mungkin juga dapat berpasangan dengan phospolipase C. Melanokortin berikatan dengan reseptornya yaitu MC1R pada permukaan melanosit kemudian mengaktifkan enzim fosfolipase $\mathrm{C}$ yang melekat pada bagian dalam tonjolan reseptor. Enzim ini selanjutnya akan menyebabkan pecahnya beberapa fosfolipid dalam membran sel menjadi inositol triphosphate $\left(\mathrm{IP}_{3}\right)$ dan diasilgliserol (DAG). $\mathrm{IP}_{3}$ terutama memobilisasi ion kalsium intraseluler dari retikulum endoplasma dan mitokondria. Kemudian ion kalsium akan membangkitkan semua efek second messenger-nya. DAG kemudian mengaktifkan enzim protein kinase $\mathrm{C}$, enzim ini memainkan peranan dalam meningkatkan proliferasi sel. ${ }^{11,35}$ 


\section{PEMBAHASAN}

Tempat utama yang menghasilkan MSH adalah pars intermedia dari kelenjar hipofisis. Karena pars intermedia pada manusia sedikit maka hanya menyekresi MSH dalam jumlah yang sedikit kecuali pada keadaan patologi. Meskipun begitu $\alpha$-MSH dan melanokortin yang lain dihasilkan juga di kulit. ${ }^{3}$ Melanokortin yang dihasilkan secara lokal di kulit dapat mengatur melanogenesis lewat mekanisme parakrin dan autokrin. ${ }^{11}$ Keratinosit dan melanosit menyekresikan melanokortin sebagai respon terhadap radiasi ultraviolet dari sinar matahari. Oleh sebab itu melanokortin dapat berperan sebagai faktor parakrin dan autokrin dalam pengaturan melanosit dan pigmentasi kulit. ${ }^{3,9,11}$

Berdasarkan penelitian Malek ZA dkk terhadap melanosit epidermal yang normal, mereka berpendapat bahwa di antara hormon-hormon melanokortin, yang sangat berperan dalam pengaturan secara fisiologi terhadap pigmentasi kulit adalah $\alpha$-MSH dan ACTH. Hal ini disebabkan karena afinitas melanosit epidermal terhadap $\alpha-\mathrm{MSH}$ atau ACTH lebih tinggi dibandingkan dengan afinitasnya terhadap $\beta$-MSH maupun $\gamma$-MSH. Dan yang paling kurang efektif adalah $\gamma$-MSH, oleh sebab itu $\gamma$-MSH tidak memiliki peran yang berarti terhadap pigmentasi kulit. ${ }^{9,11}$

Melanokortin dapat merangsang melanogenesis khususnya pembentukan eumelanin dengan meningkatkan aktifitas dari enzim tirosinase, proliferasi sel dan pembentukan dendrit terhadap melanosit epidermal. Selain itu melanokortin juga meningkatkan transfer melanosom ke keratinosit, merangsang reorganisasi sitoskeletal, merangsang perlekatan melanosit ke laminin dan fibronektin, dan menghambat TNF- $\alpha$ yang dirangsang oleh ICAM-1 pada melanosit normal dan ganas. ${ }^{3,9,11,33}$ Peningkatan sintesis eumelanin berfungsi untuk melindungi melanosit dan keratinosit dari kerusakan DNA oleh paparan sinar matahari, sehingga dapat mempertahankan kestabilan gen di melanosit dan mengurangi kesempatan pembentukan melanoma. Eumelanin tersebut akan berada di atas inti sel dan membentuk semacam perisai terhadap inti sel dari melanosit dan keratinosit yang akan melindungi DNA. , $32,36^{2}$

Peran melanokortin selain merangsang melanogenesis dan proliferasi sel juga merangsang pembentukan dendrit pada melanosit. Karena dendrit penting dalam pembentukan unit melanin epidermal dan transfer melanin, sehingga pengaturan pembentukan dendrit oleh $\alpha$ MSH menjadi sangat perlu untuk pigmentasi kulit. Akan tetapi masih belum jelas bagaimana peran $\alpha$-MSH dalam merangsang pembentukan dendrit melanosit. $^{3,11}$

\section{KESIMPULAN}

Sistem pigmentasi kulit melibatkan melanosit, melanosom, melanin, enzim tirosinase dan proses melanogenesis. Pigmentasi kulit mungkin tergantung pada beberapa pengaruh termasuk faktor keturunan/genetik (warna kulit konstitutif), hormon dan lingkungan (warna kulit fakul-tatif).

Salah satu hormon yang tergabung dalam melanokortin khusus-nya $\alpha$ MSH dan ACTH dapat merangsang melanogenesis pada melanosit dengan berikatan pada reseptornya yaitu MC1R yang terletak pada permukaan melanosit. Aktivitas dari MC1R diatur oleh faktor instrinsik dan ekstrinsik dan yang paling penting adalah radiasi ultraviolet matahari. Sebagai respon terhadap radiasi ultraviolet matahari, keratinosit dan melanosit mensekresikan melanokortin khususnya $\alpha$-MSH dan ACTH. Hormonhormon tersebut berperan sebagai faktor parakrin dan autokrin terhadap melanosit dalam pengaturan pigmentasi kulit yang diinduksi oleh radiasi ultraviolet matahari sehingga dapat melindungi dari kerusakan DNA yang dapat ditimbulkan oleh radiasi sinar ultraviolet terhadap melanosit dan keratinosit. 


\section{DAFTAR PUSTAKA}

1. Noormaini, Widjaja ES. Terbakar surya (sun burn). Berkala Ilmu Penyakit Kulit dan Kelamin 2002; 14: 1-7

2. Widianingsih NPS, Lumintang $H$. Pemakai-an tabir surya (sunscreen). Berkala Ilmu Penyakit Kulit dan Kelamin 2002; 14: 109-121

3. Tsamali M, Ancans J, Thody AJ. Melano-cyte function and its control by melanocortin peptides. J Histochem Cytochem 2002; 50(2): 125-134. Available from: http://www.jhc. org /cgi/content/full/50/5/125 (22 Mei 2006)

4. Geneser F. Buku Teks Histologi. Gunawijaya FA (alih bahasa). Jakarta: Binarupa Aksara; 1994: hal. 71-75, 240248

5. Fawcett DW. Buku Ajar Histologi. Edisi 12. Tambajong $\mathrm{J}$ (alih bahasa). Hartanto H (editor). Jakarta: EGC; 1994: hal. 477

6. Damayanti N, Listiawan MY. Fisiologi dan biokimia pigmentasi kulit. Berkala Ilmu Penyakit Kulit dan Kelamin 2004; 16: $156-162$

7. Leeson CR, Leeson TS, Paparo AA. Buku Ajar Histologi. Edisi 5. Tambajong J (alih bahasa). Jakarta: EGC; 1996: hal. 311-313

8. Cholis M. Patogenesis melasma. Majalah Kedokteran Indonesia 1995; 45: 580587

9. Malek ZA. The Melanocortin-1 receptor and human pigmentation. Ann NY Acad Sci 1999; 885: 117-133

10. Wikipedia. Melanocyte-stimulating hormone. Available from: http://en.wikipedia. org/wiki/melanocyte-stimulating hormone (cited 24 Juni 2006)

11. Slominski A. Melanin pigmentation in mammalian skin and its hormonal regulation. Phys Rev 2004; 84: 11551228. Available from: http://physrev. physiology.org/cgi/content/full//84/4/115 5 (23 Mei 2006)

12. Kalangi SJR. Penuntun teori dan praktikum histologi: Integumen. Manado: Bagian Anatomi Histologi FK Unsrat; 2004

13. Hammersen F. Sobotta/Hammersen Histology, Color Atlas of Microscopic Anatomy. Urban \& Schwarzenberg, Baltimore. 1985: p.206. Available from: http://www.esg.montana.edu/ esg/kla/ta/stratum/jpg (20 Agustus
2006)

14. Jimbow K. Biology of melanocyte. In: Fitzpatrick TB. Dermatology in General Medicine. $4^{\text {th }}$ ed. New York: Mc Graw-Hill; 1993: p.261-285

15. Fitrie A. Histologi dari melanosit. 2004. Available from: http://library.usu.ac.id (22 Mei 2006)

16. Nordlund JJ. Introduction to the biology of the pigment system. In: Moschella SL, Hurley HJ. Dermatology. $3^{\text {rd }}$ ed. Philadelphia: W.B. Saunders Company; 1992: p.1471-1438

17. Nordlund JJ, Lorton CA. Disorders of pigmentation. In: Orkin M, Maibach HI, Dahl MV. Dermatology. $1^{\text {st }}$ ed. Connecticut: Appleton \& Lange; 1991: p.261-267

18. Kiernan J. Development of the nervous system. Available from: http://www. publish.uwo.ca/ jkiernan/anfound.htm (20 Agustus 2006)

19. Anonimus. Veterinary histology. Available from: http://education. Vetmed.vt. edu/Curriculum/VM8054/Labs/Lab14/ EXAMPLES/Exmelano.htm (12 Juli 2006)

20. Wang B. The physiology of skin. 2000. Available from: http://sprojects.mmi mcgill.ca/dermatology/physiology.htm (13 Juli 2006)

21. Christina M, Agusni I. Zat-zat pemutih kulit (skin bleaching agents). Berkala Ilmu Penyakit Kulit dan Kelamin 1994; 6: 245-269

22. Anonimus: Melanocortin receptors (MC1R; MC2R; MC3R; MC4R; and MC5R) antibodies. 1996. Available from: http:// www.4adi.com (2 Agustus 2006)

23. King RA, Summers CG, Haefemeyer JW, LeRoy B. Facts about albinism. Available from: http://www www.albinism.med.umn. edu/facts.htm (20 Agustus 2006)

24. Catania A, Gatti S, Colombo G, Lipton JM. Targetting melanocortin receptors as a novel strategy to control inflammation. Pharmacol Rev 2004; 56: $1-29$

25. Roberts DW. Quantitative analysis of MC1R gene expression in human skin cell cultures. Pigment cell res 2006; 19: $76-78$

26. Gantz I, Fong TM. The melanocortin system. AJP Endocrinol Metab 2003; 
284: E468-E474

27. Messer WS. Pituitary hormones II 2000. Available from: http://www.neurosci. pharm. utoledo.edu (18 Agustus 2006)

28. Anonimus. POMC processing. Available from: http://www.copewithcytokines.de/ cope504.cgi?012040 (18 Agustus 2006)

29. Rees JL. The melanocortin 1 reseptor (MC1R): more than just red hair. Pigment Cell Res 2000; 13: 135-140. Available from: http://www.derm.med. ed.ac.uk/PDF/morethajustredhair.pdf (30 Juli 2006)

30. Rees JL. Genetics of hair and skin color. Ann Rev Genet 2003; 37: 67-90. Available from: http://www.derm.med. ed.ac.uk (5 Juni 2006)

31. Denef C. Research projects. 2002. Available from: http://www.med.kuleuven.ac.be/ farmaco (20 Mei 2006)

32. Anonimus. MC1R. 2005. Available from: http://ghr.nlm.nih.gov/gene=mc1r Agustus 2006)

33. Muceniece R. Melanocortin receptors: from cloning to selective ligands. 1999. Available from: http://www3.acadlib.iv/ greydoc/mucenieces-disertacija/ diserta-cija.doc (18 Agustus 2006)

34. Lee MR. MC4R variants and measures of adiposity in the general population. 2006. (Cited 20 september 2006)

35. Guyton \& Hall. Buku Ajar Fisiologi. Edisi 9. Setiawan I (editor). Jakarta: EGC; 1997: hal. 1159-1169, 1216

36. Chin L. Advances in malignant melanoma: genetic insights from mouse and man. Bioscience 2006; 11 : 928-942. Available from: http://www.bioscience. org/2006/v11/af/1849/fig2.jpg.files (18 Agustus 2006). 